\title{
INTEGRASI MODEL PEMBELAJARAN ROLE PLAYING DENGAN MULTIMEDIA DALAM MENINGKATKAN KETERAMPILAN PARTISIPASI SOSIAL SISWA
}

\author{
Apriyanda Kusuma Wijaya \\ Institut Agama Islam Negeri (IAIN) Syekh Nurjati Cirebon \\ apriyandawijaya@syekhnurjati.ac.id
}

\begin{abstract}
ABSTRAK
Penelitian ini bertujuan untuk menguji, menemukan pengaruh dan perbedaan penerapan integrasi model role playing dengan multimedia terhadap keterampilan partisipasi sosialsiswa pada pembelajaranpendidikan kewarganegaraan. Penelitian ini dilandasi oleh teori pengajaran sosial Bruce Joyce, dengan menggunakan pendekatan kuantitatif metode quasi eksperimen atau eksperimen semu. Populasi penelitian ini adalah siswa SMK Telkom Bandung dan sampel penelitianini adalah siswa kelas $\mathrm{X}$ MM-2 sebagai kelas eksperimen dan kelas X MM-3 sebagai kelas kontrol. Instrumen penelitian yang digunakan adalah observasi, tes, dan angket.Pengolahan dan analisis data menggunakan ujistatistik inferensial parametrik. Hasil penelitian ini menunjukkan bahwa terdapat pengaruh integrasi model role playing dengan multimedia terhadap keterampilan partisipasi sosial siswa, pengaruh itu ditunjukkan dengan adanya perbedaan keterampilan partisipasi sosial siswa. Hasil skor angket kelas yang menggunakan integrasi model role playing dengan multimedia lebih besar dibandingkan kelas yang menggunakan metode konvensional.
\end{abstract}

Kata Kunci :, Keterampilan Partisipasi, Multimedia, Role Playing.

\begin{abstract}
This study aims to test, find the effect and differences in the application of the integration of models role playing with multimedia on social participation skills of students in citizenship education learning. This research is based on Bruce Joyce's social teaching theory, using a quantitative approach to quasi-experimental methods. The population of this research is students of Telkom Bandung and the sample of this study is students of X MM-2 as an experimental class and X MM-3 as a control class. The research instruments used were observation, tests and questionnaires. Data processing and analysis usingstatistical parametric inferentialtests. The results of this study indicate that there is an influence of the integration ofmodels role playing with multimedia on students'social participation skills, the effect is indicated by differences in students' social participation skills. The results of class questionnaire scores that use integration of models role playing with multimedia are greater than classes using conventional methods.
\end{abstract}

Keywords: Multimedia, Participatory Skills, Role Playing.

\section{A. PENDAHULUAN}

Pendidikan menjadi instrument penting dalam mempersiapkan generasi terbaik bagi negara, pada pasal 03 Undang-Undang Nomor 20 tahun 2003 tentang

Jurnal Edueksos Vol. IX, No.1 Juni 2020

He journal of social and economics education 
Sistem Pendidikan Nasional dijelaskan bahwa tujuan pendidikan nasional adalah mengembangkan potensi siswa agar menjadi manusia yang beriman dan bertakwa kepada Tuhan Yang Maha Esa, berakhlak mulia, sehat, berilmu, cakap, kreatif, mandiri, dan menjadi warga negara yang demokratis serta bertanggung jawab. Dalam mewujudkan tujuan tersebut tentunya melibatkan banyak komponen seperti guru, kurikulum, sarana dan prasarana, lingkungan, dan siswa itu sendiri. Guru memegang peranan yang cukup penting bagi kualitas pendidikan, untuk itu sebuah keharusan seorang guru memiliki kompetensi yang baik, dalam Undang-Undang Nomor 14 Tahun 2005 tentang Guru dan Dosen, Pasal 10 ayat (1) menyatakan bahwa "Kompetensi guru meliputikompetensi pedagogik, kompetensi kepribadian, kompetensi sosial, dan kompetensi profesional yang diperoleh melalui pendidikan profesi”. Kompetensi pedagogik merupakan kemampuan memahami siswa, memahami perancangan dan pelaksanaan pembelajaran, memahami proses evaluasi hasil belajar, serta pengembangan siswa untuk mengaktualisasikan berbagai potensi yang dimilikinya. Dalam pelaksanaan pembelajaran tersebut tentunya harus dapat menarik perhatian siswa agar antusiasme meningkat dan tidak merasa bosan. Disinilah perlunya inovasi serta variasi guru dalam melaksanakan pembelajaran agar kemampuan siswa dapat berkembang secara optimal.

Observasi yang dilakukan peneliti pada siswa SMK Telkom Bandung, pembelajaran konvensional ceramah cenderung monoton dan berakibat pada menurunnya konsentrasi serta orientasi pembelajaran bermakna kebersamaan dan partisipasi sosialbagi siswa, mengingat SMK merupakan wadah untuk mempersiapkan generasi siap kerja dan cenderung berorientasi pada hal-hal teknis.Untuk itu peneliti mengkaji permasalahan ini berdasarkan teori pengajaran sosial. Teori pengajaran sosial Joyce (2009) merupakan sebuah teori yang melandasi salah satu model belajar kooperatif, dimana didalam teori tersebut dikatakan bahwa gejala-gejala sosial yang ada didalam masyarakat bisa menjadi sebuah pembelajaran untuk diterapkan kepada siswa yang diselesaikan dengan sistem diskusi dan kerjasama didalam sebuah kelompok. Tujuan dan asumsi yang menjadi dasar pengembangan pembelajaran kooperatif dikatakan oleh Joyce (2009) antara lain untuk meningkatkan motivasi yang lebih besar dalam pembelajaran, memupuk kerjasama dalam kelompok, menghasilkan kompleksitas sosial interaksi, 
membangun penghargaan, dan meningkatkan produktifitas kemampuan sosial. Kreatifitas guru dalam mengombinasikan model belajar akan menghasilkan kompleksitas warna pembelajaran didalam kelas untuk itu bentuk model pembelajaran kooperatif ini akan lebih berwarna apabila dituangkan dalam model belajar role playing yang berbasis project based learning yang kemudian diintegrasikan dengan media pembelajaran multimedia.

Matapelajaran pendidikan kewarganegaraan merupakan mata pelajaran yang memiliki amanah untuk membentuk karakter kepribadian sosialsiswa, untuk itu dalam proses pembelajaran pendidikan kewarganegaraan harus mengembangkan tiga kompetensi utama. Winataputra (2008) mengkaji bahwa aspek-aspek atau ruang lingkup kompetensi yang hendak dikembangkan dalam pembelajaran pendidikan kewarganegaraan. Aspek-aspek kompetensi tersebut mencakup pengetahuan kewarganegaraan (civic knowledge), keterampilan kewarganegaraan (civic skills), dan watak atau karakter kewarganegaraan (civic dispositions).Didalam keterampilan kewarganegaraan tersebut terdapat dua hal secara spresifik, yaitu keterampilan intelektual (intellectual skills) dan keterampilan berpartisipasi (participatory skills).

Berdasarkan latarbelakang permasalahan yang telah dijabarkan oleh penulis, pembelajaran konvensional ceramah cenderung monoton dan berakibat pada menurunnya konsentrasi serta orientasi pembelajaran bermakna kebersamaan dan partisipasi sosial bagi siswa. Pembelajaran pendidikan kewarganegaraan yang memiliki tujuan pengembangan kompetensi keterampilan partisipasi sosial menjadi salah satu mata pelajaran yang penting bagi siswa di SMK agar memiliki keterampilan partisipasi sosial yang baik. Untuk mencari solusi dari permasalahan tersebut peneliti tertarik untuk mengetahui perkembangan keterampilan partisipasi sosialsiswa dengan menggunakan integrasi model dengan multimedia sebagai upaya modernisasi dan peningkatan efektifitas pembelajaran. Untuk itu penelitian ini adalah untuk mengetahui perbedaan keterampilan partisipasi sosialsiswa pada pembelajaran Pendidikan kewarganegaraan yang menerapkan integrasi model role playing multimedia dengan siswa yang memperoleh pembelajaran konvensional ceramah. Hipotesis penelitian ini adalah terdapat perbedaan keterampilan partisipasi sosial antara siswa yang memperoleh pembelajaran 
menggunakanintegrasi model role playing multimedia dengan siswayang memperoleh pembelajaran konvensional ceramah

\section{Teori Pengajaran Sosial dan Cooperatif Learning}

Teori pengajaran sosial Joyce(2009) merupakan sebuah teori yang melandasi salah satu model belajar kooperatif, dimana didalam teori tersebut dikatakan bahwa gejala-gejala sosial yang ada didalam masyarakat bisa menjadi sebuah pembelajaran untuk diterapkan kepada siswa yang diselesaikan dengan sistem diskusi dan kerjasama didalam sebuah kelompok. Guru dalam ilustrasi yang diceritakan buku Joyce menunjukkan bahwa masing-masing memiliki strategi yang berbeda untuk mengajari siswa-siswanya bekerjasama secara produktif. Mereka berpedoman pada beberapa buku seperti; Circle of learningand Cooperative Learning in the ClassroomJohnson D; Johnson R; Holobec,(1994), serta Cooperative Learning Resource for Teachers Kagan (1990). Masing-masing buku sama-sama mengajari siswa mempelajari bagaimana mereka bisa bekerjasama secara efektif, serta merencanakan rancangan aktivitas selanjutnya untuk mengajari siswa bekerjasama secara lebih efektif.

\section{Integrasi Model Role Playingdan Multimedia}

Integrasi merupakan sebuah penggabungan/ pembauran dari dua atau lebih unsur menjadi satu kesatuan, dalam proses pembelajaran peran serta sebuah penerapan model yang sesuai itu juga menjadi hal yang penting. Salah satu model yang dapat digunakan untuk mengekspresikan semangat dan pengetahuan adalah model role playing.Menurut Joyce (2009: 329) esensi role playing adalah keterlibatan partisipan dan peneliti dalam situasi masalah yang sebenarnya dan adanya kegiatan untuk memunculkan resolusi damai serta memahami apa yang muncul dari keterlibatan tersebut. Proses role playing berperan untuk (1) mengeksplore perasaan siswa, (2) mentransfer dan mewujudnya pandangan mangenai perilaku, nilai, dan persepsi siswa, (3) mengembangkan skill pemecahan masalah dan tingkahlaku, (4) mengeksplorasi materi pelajaran dalam cara yang berbeda.Hersted (2017) berpendapat bahwadialogic role-playing combined with a polyphonic reflecting team can serve as a significant tool in the development of dialogical and relational skills, the practice outlined here draws attention to the 
ways in which we use language in constituting reality, our relations, our identities, and the creation of new opportunities in our social worlds.

Wicaksono (2016) menyatakan bahwa model role playing memiliki dua macam pengertian. Pertama, bermain peran merupakan kegiatan yang sifatnya sandiwara. Maksudnya terdapat beberapa pemain atau tokoh yang memainkan suatu peran tertentu, peran tersebut sesuai dengan tokoh yang telah ditulis dalam skenario, dan tujuan dari bermain peran ini salah satunya untuk memberikan hiburan pada orang lain. Kedua, model bermain peran merupakan suatu kegiatan yang bersifat sosiologis, di mana pola - pola dalam berperilaku yang ditunjukkan oleh seseorang, ditentukan oleh norma sosial yang hidup di masyarakat. Dalam pembelajaran, model ini menjadi sebuah alternative yang dimaksudkan agar siswa terhibur juga terbelajarkan.Mezirow's (2000) berpendapat bahwa transformative learning theory, the practice emphasized working with disorienting dilemmas, recognizing others' perspectives, challenging taken-for-granted assumptions, developing self-reflexivity, and experimenting with new roles. Menurut teori belajar transformatif, praktik ini (role playing) menekankan bekerja dengan mengenali perspektif orang lain, mengembangkan refleksifitas diri, dan mengembangkan kemampuan bereksperimen dengan peran baru.

Penelitian ini juga menekankan adanya penggunaan multimedia dalam pembelajaran, yang diintegrasikan dalam model role playing tersebut. Komalasari dan Saripudin (2017: 10) bahwa "multimedia interaktif dalam pembelajaran ilmu sosial adalah integrasi nilai-nilai kehidupan dan IPS bahan ke dalam multimedia interaktif pembelajaran dengan melibatkan siswa melalui praktik yang terintegrasi di dalam kelas. Model ini dilakukan melalui beberapa langkah: negosiasi materi pelajaran dan karakter, presentasi materi, pembagian kelompok berdasarkan topik ilmu sosial dari SMP, eksplorasi nilai-nilai karakter sesuai dengan topik, dan praktek terpadu (awal observasi ke sekolah, pengembangan skenario multimedia, produksi multimedia, simulasi multimedia di dalam kelas, dan praktek tentang penggunaan multimedia di sekolah). Ada perbedaan yang signifikan antara kelas yang menggunakan berbasis nilai-multimedia interaktif melalui praktek terintegrasi dengan yang dari kelas konvensional". 
Untuk langkah dan tahapan pelaksanaan pembelajaran integrasi model role playingdengan multimedia ini juga mengadopsi dari yang disampaikan oleh Joyce (2009), kemudian langkah dari pelaksanaan Integrasi model role playingdengan multimedia oleh Wijaya, Rahmat dan Komalasari (2018) berkembang menjadi sebagai berikut:Tahap pertama, mengorientasikan tentang model yang akan diterapkan yaitu menampilkan powerpoint materi pembelajaran, video pembelajaran yang berkaitan dengan materi pembelajaran, serta mengidentifikasikan kaitannya dengan materi pembelajaran;Tahap kedua, Menentukan kelompok untuk pemeranan yaitu menganalisi peran, memilih pemain yang akan melakukan peran; Tahap ketiga, mempersiapkan peneliti yaitu memutuskan apa yang akan dicari, memberikan tugas pengamatan; Tahap keempat, pemeranan yaitu memulai role playing, mengukuhkan role playing, menyudahi role playing;Tahap kelima, berdiskusi dan mengevaluasi yaitu mereview pemeranan (kejadian, posisi, dan kenyataan), mendiskusikan focus-fokus utama, mengembangkan pemeranan selanjutnya; Tahap keenam, memerankan kembali yaitu memainkan peran yang diubah, memberi masukan atau altenatif perilaku dalam langkah selanjutnya; Tahap ketujuh, berbagi dan menggeneralisasi pengalaman yaitu menghubungkan situasi yang bermasalah dengan kehidupan didunia nyata serta masalah-masalah yang baru muncul, menjelaskan prinsip umum dalam tingkah laku; Tahap kedelapan, mempersiapkan dan membuat hasil pembelajaran yaitu menuangkan ulang makna dari yang diperankan kelompok ke dalam bentuk video pembelajaran yang dibuat kelompok.

\section{Keterampilan Partisipasi Sosial}

Pendidikan Kewarganegaraan merupakan sebuah dimensi pembelajaran yang dinamis, sebagaimana dijelaskan oleh Winataputra (2012) berdasarkan perkembangan yang mutakhir, pendidikan kewarganegaraan memiliki tujuan yakni membangun partisipasi yang bermutu dan bertanggungjawab dari warga Negara dalam berkehidupan politik maupun masyarakat. Menurut Branson dalam Winataputra (2012: 199) berdasarkan kompetensi yang perlu dikembangkan, terdapat tiga komponen utama yang perlu dipelajari dalam PKn yaitu civic knowledge, civic skills, dan civic dispositions. Al Muchtar, (2000) Aspek kompetensi pengetahuan kewarganegaraan (civic knowledge) menyangkut 
kemampuan akademik keilmuan yang dikembangkan dari berbagai teori atau konsep politik, hukum dan moral. Secara lebih terperinci, materi pengetahuan kewarganegaraan meliputi pengetahuan tentang hak dan tanggung jawab warga negara, hak asasi manusia. prinsip-prinsip dan proses demokrasi, lembaga pemerintah dan nonpemerintah, identitas nasional, pemerintahan berdasar hukum (rule of law) dan peradilan yang bebas dan tidak memihak, konstitusi, serta nilainilai dan norma-norma dalam masyarakat. Keterampilan kewarganegaraan (civic skills) meliputi keterampilan intelektual (intellectual skills) dan keterampilan berpartisipasi (participatory skills) dalam kehidupan berbangsa dan bernegara.

Watak/ karakter kewarganegaraan (civic dispositions) sesungguhnya merupakan dimensi yang penting dalam mata pelajaran Pendidikan Kewarganegaraan. Dimensi watak/ karakter kewarganegaraan dapat dipandang sebagai "muara" dari pengembangan kedua dimensi sebelumnya. Dengan memperhatikan visi, misi, dan tujuan mata pelajaran Pendidikan Kewarganegaraan, karakteristik mata pelajaran ini ditandai dengan penekanan pada dimensi watak, karakter, sikap dan potensi lain yang bersifat afektif. Menurut Winarno (2006) watak, karakter, sikap atau kebiasaan hidup sehari-hari yang mencerminkan warga negara yang baik itu misalnya sikap religius, toleran, jujur, adil, demokratis, menghargai perbedaan, menghormati hukum, menghormati hak orang lain, memiliki semangat kebangsaan yang kuat, memiliki rasa kesetiakawanan sosial.

Untuk mengidentifikasi keterampilan partisipasi, lazimnya mengunakan istilah seperti, kemampuan untuk mempengaruhi kebijakan dan keputusan dengan bekerjasama dengan yang lain, memaparkan dengan gamblang suatu masalah yang penting sehingga membuatnya diketahui oleh para pembuat kebijakan dan keputusan, membangun koalisis, negosiasi, kompromi, dan mencari konsensus, mengelola konflik.Keterampilan partisipasi warga Negara menurut Wijaya (2018) dapat diketahui melalui beberapa hal seperti berinteraksi serta berkomunikasi terhadap obyek yang berkaitan dengan masalah-masalah publik, memantau/memonitor masalah politik dan pemerintahan terutama dalam penanganan persoalan-persoalan publik, sehingganya nantinya dapat mempengaruhi proses politik yang ada dimasyarakat. 


\section{B. METODE PENELITIAN}

Penelitian ini menggunakan pendekatan kuantitatif dengan metode yang digunakan kuasi eksperiment atau eksperimen semu. Desain penelitiannya yaitu pretest dan posttest Control Groub. Pada variasi metode ini observasi di bawah kondisi buatan (artificial condition) yang mana kondisi tersebut dibuat dan diatur oleh peneliti. Nantinya dalam penelitian ini terdapat dua kelompok yang dipilih secara acak, kemudian diberi pretest untuk mengetahui keadaan awal, yakni adakah perbedaan antara kelompok eksperimen dan kelompok kontrol. Jika pretest sama secara signifikan, maka kelompok tersebut sudah sesuai dengan kelompok yang akan digunakan untuk eksperimen. Selanjutnya kelompok eksperimen akan menerima perlakuan dengan pembelajaran yang menerapkan integrasi model role playing dengan multimedia dan kelompok kontrol tidak menerima perlakuan atau pembelajaran dengan konvensional ceramah.

Populasi dalam penelitian ini adalah siswa di SMK Telkom Bandung yang terdiri dari 25 rombongan belajar kelas dengan jumlah keseluruhan 858 siswa.Sampel dalam penelitian ini ditentukan berdasarkan karakteristik siswa di kelas yang setara dari jenjang kelas, aktifitas dan kreatifitas siswa dalam pembelajaran berdasarkan pengalaman peneliti dan guru-guru lain yang mengajar. Maka diambil 2 kelas yakni siswa kelas X MM-2 sebagai kelas Eksperimen dan kelas X MM-3 sebagai kelas control. Instrumen penelitian yang digunakan adalah observasi, tes dan angket yang sebelumnya telah diuji coba dan dinyatakan valid dan tingkat realibilitas sangat baik.Analisis data menggunakan menggunakan ujistatistik inferensial parametricdengan bantuan software statistik SPSS.Variabel dalam penelitian ini ada dua yaitu Integrasi model role playing dengan multimedia sebagai variabel bebas $(\mathrm{X})$ dan keterampilan partisipasi sosialsiswa sebagai variabel terikat (Y).

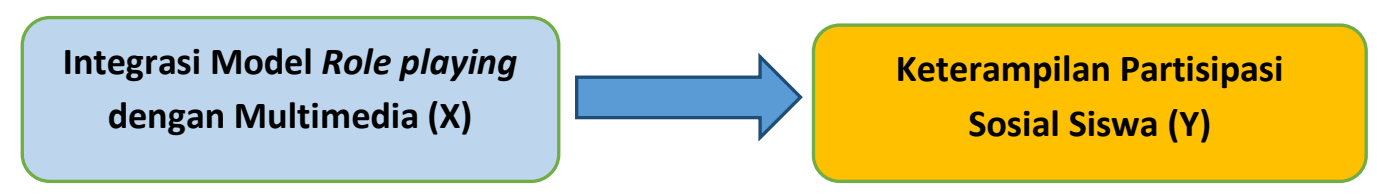

Gambar 1. Hubungan Antar Variabel

\section{HASIL DAN PEMBAHASAN}

Jurnal Edueksos Vol. IX, No.1 Juni 2020

He journal of social and economics education 


\section{Kondisi Keterampilan Partisipasi Sosial Kelas Eksperimen dan Kontrol}

Hasil pengolahan data penelitian tentang keterampilan partisipasi pada kelas eksperimen dan kontrol berdasarkan Pre-testdanPost-test dapat dilihat tabel di bawah ini:

\section{Tabel 1}

Perbandingan Hasil Nilai Rata-Rata Pre-test dan Post-test Keterampilan Partisipasi Sosial pada Kelas Eksperiman dan Kelas Kontrol

\begin{tabular}{|c|c|c|c|c|c|c|c|c|c|}
\hline \multirow{3}{*}{ No. } & \multirow{3}{*}{ Indikator } & \multicolumn{4}{|c|}{ Kelas Eksperimen } & \multicolumn{4}{|c|}{ Kelas Kontrol } \\
\hline & & \multicolumn{2}{|c|}{ Rata-Rata } & \multicolumn{2}{|c|}{ Peningkatan } & \multicolumn{2}{|c|}{ Rata-Rata } & \multicolumn{2}{|c|}{ Peningkatan } \\
\hline & & $\begin{array}{l}\text { Pre- } \\
\text { test }\end{array}$ & $\begin{array}{l}\text { Post- } \\
\text { test }\end{array}$ & $\begin{array}{l}\text { Rata- } \\
\text { Rata }\end{array}$ & $\%$ & $\begin{array}{l}\text { Pre- } \\
\text { test }\end{array}$ & $\begin{array}{l}\text { Post- } \\
\text { test }\end{array}$ & $\begin{array}{l}\text { Rata- } \\
\text { Rata }\end{array}$ & $\%$ \\
\hline 1 & $\begin{array}{l}\text { Kemampuan } \\
\text { Partisipasi Umum }\end{array}$ & 3,90 & 4,43 & 0,53 & 52,78 & 3,95 & 3,99 & 0,05 & 4,51 \\
\hline 2 & $\begin{array}{l}\text { Keahlian } \\
\text { Pemecahan } \\
\text { Masalah }\end{array}$ & 3,84 & 4,45 & 0,61 & 61,46 & 3,85 & 3,91 & 0,06 & 6,25 \\
\hline & Jumlah & 7,74 & 8,88 & 1,14 & 114,24 & 7,80 & 7,90 & 0,11 & 10,76 \\
\hline
\end{tabular}

Berdasarkan tabel 1 di atas dapat diketahui bahwa nilai rata-rata sub-indikator kemampuan partisipasi umum pada pre-test kelas eksperimen adalah sebesar 3,90 dan nilai rata-rata pada post-test adalah 4,43 dengan demikian dapat disimpulkan bahwa antara hasil pre-test dengan post-test mengalami kenaikan sebesar 0,53 atau $52,78 \%$. Kemudian nilai rata-rata sub-indikator keahlian pemecahan masalah pada pre-test kelas eksperimen adalah sebesar 3,86 dan nilai rata-rata pada post-test adalah 4,45 dengan demikian dapat disimpulkan bahwa antara hasil pre-test dengan post-test mengalami kenaikan sebesar 0,61 atau $61,46 \%$.

Sedangkan pada kelas kontrol dapat diketahui bahwa nilai rata-rata subindikator kemampuan partisipasi umum pada pre-test adalah sebesar 3,95 dan nilai rata-rata pada post-test adalah 3,99 dengan demikian dapat disimpulkan bahwa antara hasil pre-test dengan post-test mengalami kenaikan sebesar 0,05 atau 4,51\%. Kemudian nilai rata-rata sub-indikator keahlian pemecahan masalah pada pre-test kelas kontrol adalah sebesar 3,85 dan nilai rata-rata pada post-test adalah 3,91 dengan demikian dapat disimpulkan bahwa antara hasil pre-test dengan post-test mengalami kenaikan sebesar 0,06 atau $6,25 \%$. 
Dari penjabaran data kelas eksperimen di atas antara hasil nilai rata-rata pretest dengan post-test ternyata terjadi peningkatan nilai rata-rata yang cukup stabil, pada sub indikator kemampuan partisipasi umum mengalami kenaikan sebesar 0,53 atau 52,78\% dan pada keahlian pemecahan masalah mengalami kenaikan sebesar 0,61 atau $61,46 \%$. Kemudian pada kelas kontrol nilai rata-rata sub-indikator kemampuan partisipasi umum mengalami kenaikan sebesar 0,05 atau 4,51\% dan pada sub-indikator keahlian pemecahan masalahmengalami kenaikan sebesar 0,06 atau $6,25 \%$.

Berdasarkan data tersebut dapat diambil nilai rata-rata keseluruhan peningkatan keterampilan partisipasi pada kelas eksperimen adalah sebesar 0,57 atau 57,12\% dan pada kelas kontrol adalah 0,05 atau 5,38\%.Jadi dari analisis tersebut menghasilkan sebuah kesimpulan bahwa keterampilan partisipasi pada kelas eksperimen lebih baik daripada keterampilan intelektual kelas kontrol, hal tersebut karena pada kelas eksperimen yang melakukan pembelajaran Pendidikan kewarganegaraan menggunakan Integrasi model role playing dengan multimedia lebih berpartisipasi dalam mengikuti pembelajaran, mengerjakan tugas pembelajaran dan lebih bisa menerapkan hasil keterampilan intelektual mereka pada saat melakukan pemeranan dan membuat tugas project hasil pembelajaran.

\section{Perbedaan Keterampilan Partisipasi SosialSiswa antara Kelas Eksperimen dan Kelas Kontrol}

Untuk menganalisis perbedaan keterampilan partisipasi sosialsiswa pada pembelajaran Pendidikan kewarganegaraan antara kelas eksperimen dan kelas kontrol, dapat dilakukan dengan melihat hasil mean pretes dan postes. Agar lebih jelas mengenai gambaran umum hasil penelitian tersebut dapat dilihat melalui tabel sebagai berikut:

\section{Tabel 2}

Perbandingan Keterampilan Partisipasi Sosial Pretes-Postes Kelas Eksperimen dan Kelas Kontrol

\section{Group Statistics}

\begin{tabular}{|l|l|r|r|r|r|}
\hline & Kelas & \multicolumn{1}{|c|}{$\mathrm{N}$} & \multicolumn{1}{|c|}{ Mean } & Std. Deviation & \multicolumn{1}{c|}{ Std. Error Mean } \\
\hline \multirow{2}{*}{ Preetest } & Eksperimen & 36 & 61,9167 & 6,98723 & 1,16454 \\
& Kontrol & 36 & 62,3611 & 7,42641 & 1,23774 \\
\multirow{2}{*}{ Posttest } & Eksperimen & 36 & 69,3611 & 8,05336 & 1,50889 \\
& Kontrol & 36 & 63,2222 & 7,53321 & 1,25553 \\
\hline
\end{tabular}


Dari tabel 2 diatas dapat diperoleh informasi bahwa pada saat pretes keterampilan partisipasi pada kelas eksperimen memperoleh mean 61,917 sedangkan pada kelas kontrol memperoleh 62,361. Hal tersebut menunjukkan perbedaan nilainya hanya 0,45 atau bisa dianggap hampir tidak ada selisih dari kedua kelas tersebut. Berbeda dengan setelah dilakukannya postes dimana kelas eksperimen mendapatkan perlakuan dengan Integrasi model role playing dengan multimedia dan kelas kontrol mendapatkan model pembelajaran konvensional, sehingga mean keterampilan partisipasi kelas eksperimen memperoleh 69,36 dan kelas kontrol mendapatkan 63,22. Dengan demikian dapat diketahui perbedaan mean keterampilan partisipasi pada kelas eksperimen jauh lebih besar dibandingkan kelas kontrol.

Uji normalitas dan uji homogenitas data pretes dan postes keterampilan partisipasi social telah dilakukan dengan SPSS 20 dan berdistribusi normal, setelah diketahui bahwa data postes keterampilan partisipasi pada kelas eksperimen dan kontrol berdistribusi normal, maka dapat dianalisis dengan menggunakan data Uji$\mathrm{T}$ dengan rumusan hipotesis sebagai berikut:

$\mathrm{H}_{0} \quad$ : Tidak terdapat perbedaan keterampilan partisipasi antara siswa pada kelas yang menggunakan Integrasi model role playing multimedia dengan kelas yang menggunakan pembelajaran konvensional.

$\mathrm{H}_{1}$ : Terdapat perbedaan keterampilan partisipasi antara siswa pada kelas yang menggunakan Integrasi model role playing multimedia dengan kelas yang menggunakan pembelajaran konvensional.

Untuk lebih jelas dalam melihat hasil pengujian hipotesis tersebut maka dapat dilihat melalui tabel dibawah ini:

Tabel 3

Independent Samples Test

\begin{tabular}{|c|c|c|c|c|c|c|c|c|}
\hline \multicolumn{2}{|c|}{$\begin{array}{c}\text { Levene's Test } \\
\text { for Equality of } \\
\text { Variances }\end{array}$} & \multicolumn{7}{|c|}{ t-test for Equality of Means } \\
\hline \multirow[t]{2}{*}{$\mathrm{F}$} & \multirow[t]{2}{*}{ Sig. } & \multirow[t]{2}{*}{$\mathrm{T}$} & \multirow[t]{2}{*}{ Df } & \multirow[t]{2}{*}{$\begin{array}{l}\text { Sig. (2- } \\
\text { tailed) }\end{array}$} & \multirow[t]{2}{*}{$\begin{array}{c}\text { Mean } \\
\text { Differen } \\
\text { ce }\end{array}$} & \multirow{2}{*}{$\begin{array}{c}\text { Std. } \\
\text { Error } \\
\text { Differen } \\
\text { ce }\end{array}$} & \multicolumn{2}{|c|}{$\begin{array}{l}95 \% \text { Confidence } \\
\text { Interval of the } \\
\text { Difference }\end{array}$} \\
\hline & & & & & & & Lower & Upper \\
\hline
\end{tabular}




\begin{tabular}{|c|c|c|c|c|c|c|c|c|c|c|}
\hline Preetest & $\begin{array}{l}\text { Equal } \\
\text { variances } \\
\text { assumed }\end{array}$ & 12 & ,73 &,- 26 & 70 & ,79 &,- 44 & 1,69 & $-3,83$ & 2,94 \\
\hline & $\begin{array}{l}\text { Equal } \\
\text { variances not } \\
\text { assumed }\end{array}$ & & &,- 26 & 69,74 & ,79 &,- 44 & 1,69 & $-3,83$ & 2,94 \\
\hline Posttest & $\begin{array}{l}\text { Equal } \\
\text { variances } \\
\text { assumed }\end{array}$ & 19,16 & ,00 & 4,53 & 70 & ,00 & 6,13 & 1,35 & 3,43 & 8,84 \\
\hline & $\begin{array}{l}\text { Equal } \\
\text { variances not } \\
\text { assumed }\end{array}$ & & & 4,53 & 46,19 & 00 & 6,13 & 1,35 & 3,41 & 8,86 \\
\hline
\end{tabular}

Uji Perbedaan Keterampilan Partisipasi Sosial

Berdasarkan hasil perhitungan SPSS 20 pada tabel 3 diketahui bahwa postes keterampilan partisipasi memiliki nilai Sig.(2-tailed) atau P-Value sebesar 0,00. Karena nilai Sig.(2-tailed) $0,00<0,05$ maka bermakna $\mathrm{H}_{0}$ ditolak dan $\mathrm{H}_{1}$ diterima pada $\alpha=5 \%$. Jadi kesimpulannya yaitu "terdapat perbedaan keterampilan partisipasi sosialantara siswa pada kelas yang menggunakan integrasi modelrole playing multimedia dengan kelas yang menggunakan pembelajaran konvensional ceramah".

\section{a. Analisis Gain Score Keterampilan Partisipasi Sosial}

Analisis gain score merupakan cara analisis data dari desain eksperimen dengan mencari nilai selisih dari nilai postes dan pretes antara kelas eksperimen dan kelas kontrol. Untuk lebih jelas dalam memahami perbandingan gain score dapat dilihat dari tabel dibawah ini:

Tabel 4

Gain ScoreKeterampilan Partisipasi Sosial Group Statistics

\begin{tabular}{|l|l|r|r|r|r|}
\hline & Kelas & $\mathrm{N}$ & \multicolumn{1}{|c|}{ Mean } & \multicolumn{1}{c|}{ Std. Deviation } & \multicolumn{1}{c|}{ Std. Error Mean } \\
\hline \multirow{2}{*}{ gain_score } & Eksperimen & 36 & 7,4444 & 5,90130 &, 98355 \\
& Kontrol & 36 &, 8611 & 1,07312 &, 17885 \\
\hline
\end{tabular}

Berdasarkan tabel 4 gain score diatas, selisih nilai rata-rata hasil postes dan pretes pada kelas eksperimen sebesar 7,44 sedangkan pada kelas kontrol sebesar 0,86. Dari nilai tersebut menunjukkan bahwa peningkatan keterampilan partisipasi siswa pada kelas eksperimen jauh lebih tinggi dibandingkan kelas kontrol yang 
berarti bahwa penggunaan integrasi model role playingdengan multimedia signifikan terhadap peningkatan keterampilan partisipasi siswa.

\section{Integrasi Model Role playingdengan Multimedia dalam Pembelajaran Pendidikan kewarganegaraan Berpengaruh Signifikan terhadap Keterampilan Partisipasi SosialSiswa}

Integrasi model role playingdengan multimedia untuk meningkatkan keterampilan partisipasi berpengaruh secara signifikan, ditunjukkan dengan nilai rata-rata postest pada keterampilan partisipasi kelas eksperimen sebesar 4,44. Nilai tersebut jauh lebih besar dibandingkan nilai postes pada kelas kontrol. Kemudian berdasarkan pengolahan data menunjukkan selisih mean posttest yang sangat besar pada kelas eksperimen dan kelas kontrol. Penerapan Integrasi model role playing dengan multimedia berpengaruh secara signifikan terhadap keterampilan partisipasi siswa tersebut dapat dianalisis dari beberapa hal: Pertama, bertambahnya pengetahuan dari pengalaman belajar, yang kemudian membangun persepsi pada masing-masing siswa terhadap suatu permasalahan yang sedang dikaji.

Hal tersebut sejalan dengan pemahaman kontruktivisme yang dikemukakan oleh Piaget dan Vygotsky dalam Ibrahim dan Nur (2005) yang menyatakan bahwa: (a) Anak memiliki ras ingin tahu bawaan dan secara terus menerus berusaha memahami dunia sekitarnya. Rasa ingin tahu ini memotivasi mereka untuk aktif membangun gambaran-gambaran dalam otak mereka tentang lingkungan yang mereka hayati. Ketika mereka tumbuh lebih dewasa dan lebih memiliki kemampuan berbahasa dan berkemampuan mental, gambaran-gambaran mental mereka tentang dunia menjadi semakin luas dan abstrak. (b) Siswa dengan segala usia secara aktif terlibat dalam proses perolehan informasi dan membangun pengetahuan mereka sendiri, pengetahuan tidak statis tetapi terus menerus tumbuh dan berubah pada siswa menghadapi pengalaman baru yang memaksa mereka membangun dan memodifikasi pengetahuan awal mereka. (c) Pedagodik yang baik harus melibatkan anak dengan situasi-situasi dimana anak itu mandiri melakukan eksperimen, mencoba segala sesuatu untuk melihat apa yang terjadi, memanipulasi tanda-tanda, memanipulasi simbol mengajukan pertanyaan dan menemukan jawabannya, mencocokkan apa yang mereka temukan pada suatu saat dengan apa 
yang ia temukan pada saat yang lain, membandingkan temuannya dengan temuan anak lain.

Kedua, Integrasi model role playing dengan multimedia dalam pembelajaran Pendidikan kewarganegaraan dapat meningkatkan keterampilan partisipasi siswa, hal ini juga ditunjukkan dengan adanya perubahan sikap siswa dalam memandang sebuah permasalahan untuk mengambil keputusan bersama. Hal tersebut sejalan dengan yang dikemukakan oleh Joyce (2009) tentang esensi role playing yang mengatakan bahwa keterlibatan partisipan dan peneliti dalam situasi masalah yang sebenarnya dan adanya kegiatan untuk memunculkan resolusi damai serta memahami apa yang muncul dari keterlibatan tersebut. Proses role playing berperan untuk mengeksplore perasaan siswa; mentransfer dan mewujudnya pandangan mangenai perilaku, nilai, dan persepsi siswa; mengembangkan skill pemecahan masalah dan tingkahlaku; mengeksplorasi materi pelajaran dalam cara yang berbeda.

Berdasarkan hal tersebut, dapat ditegaskan bahwa dengan mengikuti pembelajaran Pendidikan kewarganegaraan yang menerapkan Integrasi model role playing dengan multimedia tersebut, siswa mendapatkan pengalaman dalam bersikap, bertingkahlaku menjadi orang lain, mengambil nilai-nilai baik dari proses pemeranan, kemudian juga melatih kemampuan dalam memecahkan masalah serta mengambil keputusan bersama. Dalam hal tersebut maka keterampilan relasional siswa berkembang, seperti halnya yang disampaikan Hersted (2017) "Dialogic roleplaying combined with a polyphonic reflecting team can serve as a significant tool in the development of dialogical and relational skills, the practice outlined here draws attention to the ways in which we use language in constituting reality, our relations, our identities, and the creation of new opportunities in our social worlds". Jadi model bermain peran secara dialogis akan mencerminkan makna penting dalam pengembangan dialogis dan keterampilan relasional, dalam prakteknya yang menarik perhatian yaitu pada cara-cara yang digunakan dalam membentuk realitas, hubungan, identitas, dan penciptaan peluang baru di dunia sosial.

Selain itu penerapan role playing dalam pembelajaran dapat mengembangkan reflektifitas dan kemampuan bereksperimen, seperti teori transformatif yang 
disampaikan oleh Mezirow's (2000) transformative learning theory, the practice emphasized working with disorienting dilemmas, recognizing others' perspectives, challenging taken-for-granted assumptions, developing self-reflexivity, and experimenting with new roles). Menurut teori belajar transformatif, praktik ini (role playing) menekankan bekerja dengan mengenali perspektif orang lain, mengembangkan refleksifitas diri, dan mengembangkan kemampuan bereksperimen dengan peran baru.

\section{KESIMPULAN}

Berdasarkan hasil analisis data menunjukkan bahwa nilai rata-rata gain antara kelas eksperimen dengan kelas kontrol berbeda, hal tersebut menunjukkan adanya pengaruh dari penerapan integrasi model role playing dengan multimedia dalam pembelajaran.Maka hipotesis dapat diterima bahwa terdapat perbedaan keterampilan partisipasi sosial antara siswa yang memperoleh pembelajaran menggunakanintegrasi model role playing multimedia dengan siswayang memperoleh pembelajaran konvensional ceramah. Pernyataan tersebut diperkuat dengan hasil persentase peningkatan nilai rata-rata keterampilan partisipasi sosial di kelas eksperimen yang jauh lebih besar dibandingkan peningkatan nilai rata-rata di kelas kontrol. Hal ini terjadi karena siswa pada kelas eksperimen dapat melakukan proses pembelajaran integrasi model role playing multimedia dengan baik. Sehingga dapat memperoleh makna pembelajaran dari pengalaman yang melatih sikap tanggung jawab dan kerjasama.

\section{REFERENSI}

Al Muchtar, Suwarma. (2000). Pengembangan Kemampuan Berpikir dan Nilai Dalam Pendidikan IPS. Bandung: Gelar Pustaka Mandiri Bandung.

Hersted, Lone. (2017).Reflective Role-Playing in the Development of Dialogic Skill. Journal of Transformative Education 2017, Vol. 15(2) 137-155. Department of Learning and Philosophy, University of Aalborg, Aalborg, Denmark. The Author(s) 2017 Reprints and permission: sagepub.com/journalsPermissions.nav DOI: $\quad 10.1177 / 1541344616686765$ journals.sagepub.com/home/jtd

Ibrahim dan Nur. (2005). Pengajaran Berdasarkan Masalah. Surabaya: University Press 
Johnson, D.W., Johnson, R.T \& Holobec, E. (1994). Circles Of Learning. Alexandria. VA: ASCD

Joyce, Bruce. Dkk. (2009). Models Of Teaching (Model-Model Pengajaran). Yogyakarta: Pustaka Pelajar.

Kagan, S., (1990). Cooperative Learning Resources For Teachers. San Juan Capistrano CA: Resources For Teachers.

Komalasari, K. dan Didin Saripudin (2017). Nilai Berbasis Interaktif Pengembangan Multimedia melalui Praktek Terpadu untuk Pembentukan Karakter Siswa.TOJET: The Turkish Online Journal of Educational Technology October 2017, volume 16 issue 4.

Mezirow, J. (2000). Learning as transformation: Critical perspectives on a theory in progress. San Francisco, CA: Jossey-Bass

Undang-Undang Nomor 14 Tahun 2005 tentang Guru dan Dosen.

Undang-Undang Nomor 20 tahun 2003 tentang Sistem pendidikan Nasional

Wicaksono, A., dkk. (2016). Teori Pembelajaran Bahasa: Suatu Catatan Singkat Edisi Revisi. Yogyakarta: Garudhawaca.

Wijaya, A. K. (2018).Pengaruh Model Bermain Peran Berbantuan Multimedia Terhadap Keterampilan Kewarganegaraan Peserta Didik. Universitas Pendidikan Indonesia.

Wijaya, A. K.,Rahmat, K.Komalasari. (2018). Reflective Experiences of Students to the Integration of Role Playing Model with Multimedia In Citizenship Education. Advances in Social Science, Education and Humanities Research, volume 251. Annual Civic Education Conference (ACEC2018)

Winarno. 2006. Pendidikan Kewarganegaraan di Perguruan Tinggi. Jakarta : Bumi Aksara Somantri.

Winataputra, Udin dan Dasim Budiansyah. (2012). Pendidikan kewarganegaraan dalam perspektif internasional. Bandung : Widya Aksara Press.

--------------, Udin. (2008). Pembelajaran PKn. Jakarta: UniversitasTerbuka. 